\title{
Öz Yeterlilik Algısı Ve Liderlik Tarzı İlişkisinde İş Tatmininin Aracılık Rolü ${ }^{1}$
}

DOI: 10.26466/opus.683963

\author{
Edip Örücü ${ }^{*}$ Cemile Şeker** -Attila Kaya*** \\ *Prof. Dr. Bandırma Onyedi Eylül Üni., İktisadi ve İdari Bilimler Fak. Balıkesir/Türkiye \\ E-Posta: eorucu@bandirma.edu.tr ORCID: 0000-0002-3301-7496 \\ **Dr. Öğrencisi, Bandırma Onyedi Eylül Üniversitesi, Sosyal Bilimler Enstitüsü, Balıkesir/Türkiye \\ E-Posta: sekercemile@gmail.com ORCID: 0000-0002-9150-6845
}

***Dr. Öğrencisi, Osmaniye Korkut Ata Üniversitesi, Sosyal Bilimler Enstitüsü, Osmaniye/Türkiye

E-Posta: akaya501616@gmail.com

ORCID: 0000-0002-2479-5173

\section{Öz}

Çalışanlarda öz yeterlilik algılamalarım etkileyen birçok iç ve dış etken bulunmakta olup, söz konusu etkenlerden birisi de liderliktir. Lider, davranışlar ve uygulamalarıyla ile personel üzerinde doğrudan etkisi olan kişidir. Bunun yanı sıra örgütsel yapıda bu iki unsuru arasındaki ilişkiye; örgüt kültürü, motivasyona ve iş tatmini gibi değişik faktörlerin doğrudan veya dolaylı etkisi de bulunmaktadır. Bu araştırmanın amact, AVM'lerde çalışan personelin, öz yeterlilik algısının liderlik tarzı ilişkisinde, iş tatminin aracıllk etkisini belirlemektedir. Çalışma, Balıkesir Edremit Bölgesinde bulunan AVM'lerde çalışan personel üzerinde gerçekleştirilmiştir. Çalışma için 250 anket dağıtılmış ve geçerli kabul edilen 201 anket veri seti olarak kullanılmıştır. Araştırma kapsamında yapısal eşitlik modellemesi ile araştırma modeli çizilmiş, değişkenlerin uyum değerlerini tespit etmek için doğrulayıcı faktör analizi yapılmıştır. Korelâsyon analizinde değişkenler arasında pozitif bir ilişki tespit edilmiş ve hipotez testleri için hiyerarşik regresyon analizi yapılmıştır. Regresyon analizleri sonucundaki bulgulara göre, liderlik tarzının öz yeterlilik algllamalar ve iş tatmini üzerinde pozitif anlamlı bir etkiye sahiptir. Ayrıca liderlik tarzı ve öz yeterlilik algısı ilişkisinde iş tatminin aracllık etkisinin pozitif yönlü (\%8) olduğu tespit edilmiştir.

Anahtar Kelimeler: $\quad$ Öz yeterlilik, Liderlik, İş tatmini, AVM

\footnotetext{
${ }^{1}$ Araştırma verileri 2018 yılı içerisinde elde edilmiştir.
} 


\title{
The Intermediate Role Of Job Satisfaction In Relationship Between Self-Quality Perception And Leadership Style
}

\begin{abstract}
The purpose of this research, personnel working in shopping malls, in the relationship of self-efficacy leadership style is to test the effect of job satisfaction intermediary role. The study was carried out on the personnel working in shopping malls in Edremit, Balıkesir. For the study, 201 questionnaires were used as a questionnaire which was distributed and accepted as valid. In the scope of the research, a research model was drawn with structural equation modeling and confirmatory factor analysis was performed to determine the adaptation values of the variables. Correlation analysis revealed a positive correlation between variables and regression analysis was performed for hypothesis testing. According to the findings of the regression analysis, it has a positive effect on the self-efficacy perception of the leadership style and job satisfaction. In addition, the mediating role of job satisfaction in the relationship between leadership style and self-efficacy perception has been found to be positive and at a rate as low as $8 \%$.
\end{abstract}

Keywords: Self-efficacy, Leadership, Job satisfaction, Shopping Center 


\section{Giriş}

İnsan faktörü, işletmelerin en önemli üretim girdilerinden birisini oluşturmaktadır. Diğer bir ifadeyle, İşletmeleri misyonunu ve vizyon hedeflerini gerçekleştirmede temel güç, insan kaynağıdır. Bu kaynağı verimli kullanmak işletmenin insan kaynakları departmanının sorumluluğundadır. Ancak özellikle de gelişmekte olan ülkelerde insan kaynağının değeri maalesef tam olarak anlaşılmış değildir. Personeli işe bağlayan olgu sadece yaptı̆̆ işten kazanacağı tutar yani ücret değildir. Sosyal haklarının tam olarak yerine getirilmesi, yaptığ 1 işten keyif alması ve işletmenin kendisine verdiği değeri tam olarak hissetmesi çalışanların hem öz yeterlilik ihtiyacın hem de iş tatmini ihtiyacını giderecektir. Ülkemizde sosyal haklar kanunlarla yeterince korunmasına rağmen birçok sektörde işletmeler hâlâ bu kuralları göz ardı etmektedirler. İşletmelerde verimliliğin artırılması ve çalışanın performansı için çok önemli olan bu kanunları, işletmeler kendi çıkarları için sadece kâğıt üzerinde olan ifadeler şeklinde kabul görmemeli ve bu kurallara tam olarak uymalıdırlar.

İnsan kaynağının iş bilgisi, iş becerisi, iş tekniği ve yeteneğinin yanı sıra iletişiminin, psikolojisinin ve sosyal zekâsının önemi kesinlikle yadsınamaz. Personelin işini severek yapması hem kendisi için hem de işletme için etkinlik ve verimlilik kavramının karşılığıdır. Bilindiği üzere işin kişiye kişinin işe uygunluğu ergonomi olarak tanımlanır. Kişinin yaptığı işte öz yeterliliği ile işten duyduğu tatminde aslında ergonominin içene giren bir kavramdır. Öz yeterlilik yani kişinin kendine olan inanc işinin gereklerini layıkıyla yerine getirmesi sadece kendi hedeflerine, kariyer planlarına giden yolda belirleyici bir faktör olmayacak aynı zamanda işletmenin de hedeflerine ulaşmasını sağlayacaktır.

Çalışanlarda öz yeterliliği etkileyen birçok iç ve dış faktör bulunmaktadır. Bu faktörlerin en önemlilerinden birisi de liderlik unsurudur. Lider, organizasyonlarda ortaya koyduğu fikirler ve yürüttüğü politikalar ile çal1şan personel üzerinde doğrudan etkisi olan kişidir. Dolayısıyla çalışanların liderlik tarzları algılamalarının, öz yeterliğe, kişisel gelişime, iş tatminine ve motivasyona olumlu katkısı bulunmaktadır.

$\mathrm{Bu}$ çalışmanın amacı çalışanların öz yeterlilik algılarının liderlik tarzı ilişkisinde ikinci bir etken olan iş tatmininin aracılık rolünün olduğunun kanıtlanmasıdır. Araştırmada değişkenlere ilişkin kavramlar açıklanmış, 
birbirleriyle olan ilişkileri incelenmiş ve bu yönde hipotezler kurulmuştur. Kurulan hipotezler bir istatistik programı aracılı̆̆ ile analiz edilmiş ve sonuç kısmında yorumlanmıştır.

\section{Öz Yeterlilik, Liderlik Ve İş Tatmini Kavramlarina Genel Bakış}

Öz yeterlilik ilk olarak Bandura (1986) tarafindan ifade edilen bir kavramdır. Öz yeterlilik konusunda çok tanım bulunmakla birlikte, Bandura tarafından ifade edilen öz yeterlilik tanımlarından bir tanesi şu şekildedir. Öz yeterlilik; kişinin performansını artırmak için gerekli tüm unsurları bir araya getirip, başarılı olarak yapabilme kapasitesine ilişkin kendine dönük algılayışı, yargısı ve inancıdır (Chen v.d. 2001,s.62). Yine Bandura tarafından yapılan bir diğer tanımda; "Muhtemel durumları yönetmek için gerekli olan eylem planlarını organize etmek ve yürütmek için kişinin kabiliyetlerine inanmasıdır" (Bandura,1995; 2).

Tanımlardan da anlaşılacağı üzere öz yeterlilik, kişinin herhangi bir sorumluluğun üstesinden gelebilmesi için (işini verimli bir şekilde gerçekleştirebilmesi için ) kendi yeteneklerinin farkına varması ve kendine olan öz inancının gücüdür. Öz yeterlilik deneyimler kanalıyla yavaşça artan karmaşık, bilişsel, sosyal, dilsel ve /veya fiziksel becerilerinden meydana gelmektedir. Buna göre Bandura (1986) öz yeterliliğin geliştirilmesinde deneyimlerin üç farklı madde altında aşağıdaki gibi toplandığını ifade etmektedir. Bunlar;

- Doğrudan deneyimler,

- Dolaylı deneyimler,

- Sosyal ikna ve kişilerin yeteneklerini hesaplarken ki psikolojik ve duygusal durumlarıdır.

Bandura'ya göre yukarıdaki bu üç madde yeterlilik algılarını etkilemekte, kişinin bilişsel değerlendirme ve bu üç maddenin birleşmesi sonucu kendi öz yeterliliğini belirlediğini ifade etmektedir. (Randhawa, 2004,s.337).

Öz yeterlik algısının boyutları Ömer Faruk İşcan ve Sezin Çakır'ın hazırlamış olduğu "Mentorluk Ve Pskolojik Güçlendirmenin Öz yeterlilik Alg1sına Etkisi" adlı çalışmasında başlama ,yılmama ve sürdürme çabası olarak 3 boyutta ele alınmıştır.

İnsanoğlu karmaşık doğası gereği çözülmesi ve anlaşılması zor bir varlıktır. Her zaman rasyonel davranacağını düşünmek büyük bir hata olacak- 
tır. Psikolojik durumu davranışlarını kişi ne kadar profesyonel olursa olsun etkilemektedir. Daha önce öz yeterliliği kendimizce tanımlamış ve kişinin kendine olan inancının gücüdür demiştik. İnsanın doğası gereği bu inanç bazen sarsılmakta ve bu güven duygusu sarsıldığında kişi ne kadar donanımlı ve yetenekli olursa olsun öz yeterliliği dolayısıyla iş tatminini de olumsuz etkilemektedir. Peki, İş tatmini nedir? Öz yeterlilik ve iş tatmini arasında nasıl bir ilişki vardır. Literatürde İş tatmini ile ilgili birçok çalışma yapılmıştır ve kaynaklarda iş tatmini aşağıdaki gibi açıklanmaktadır. İş tatmini konusunda ilk kavramsal çalışmaların, Maslow'un "İnsan İhtiyaçları Hiyerarşisi Kuramı" ve Herzberg' in "Çift Faktör Kuramı" olduğu görülmektedir (Adler vd., 1985).

Kısa bir şekilde iş tatmini, "işten elde edilen bir takım kazanımlar, çalışanın kendine sağladığı maddi ve manevi haz duygusu" olarak ifade edilebilir (Bingöl, 1997,s.270). Davis (1988) iş tatmininin, çalışanların işlerinden duydukları hoşnutluk veya hoşnutsuzluk olduğundan bahsetmiştir. Bu tanımdan yola çıkarak etkilerin çalışan üzerinde iş tatmini gibi olumlu etkileri yanında, iş tatminsizliği gibi olumsuz yönleri de bulunmaktadır. İş tatmininin etkisi konusunda üç önemli boyut vardır. Bunlar;

- İş tatmini, duyusal olan soyut bir kavramdır. Bu nedenle sadece ifade edilebilir.

- İş tatmininde önemli olan sonuçtaki etkidir. Yani sonucun fiili olarak çalışan üzerindeki etkisinin ne şekilde olduğudur.

- İş tatmini, iş konusunda önemli olan ücret, kariyer olanakları, örgüt kültürüne bağlllık ve yönetsel ilişkileri bir bütün olarak etkilemektedir. (Luthans 1995, s.172).

İşletmelerde bütün üretim girdilerini kontrol etmek ve üretime yönlendirmek insan kaynağı girdisine göre çok daha kolaydır. Ancak verimlilik ve karlılığın sağlanması daha çok insan gücü ile yakından ilişkilidir. Bu nedenle organizasyonlarda en önemli bölümün insan kaynakları departmanı olduğu söylenebilir. Çünkü daha önce ifade ettiğimiz gibi insan karmaşık bir yapıya sahiptir davranışlarını önceden kestirmek ya da sürekli rasyonel davranmasını beklemek yanlış olacaktır. Kişinin işinden almış olduğu haz ve doyum etkinliğini artıracak dolayısıyla işletme hedeflerine daha hızlı ve kolay ulaşacaktır.

Çalışanların işletme ve kendi çıkarları doğrultusunda yönlendirilmesinde ise çok önemli bir kavram olarak liderlik unsuru karşımıza çıkmaktadır. 
Liderlik kavramı yazınlarda genişçe yer bulmuş, birçok araştırmaya konu olmuş ve alanına göre farklı tanımlamalar yapılmıştır. Bunlardan bazıları aşağıdaki gibidir.

- Graen (1976); Liderlik; grup üyeleri ve lider arasında karş1lıklı iletişimin bulunduğu, yönetsel bir süreçtir.

- Etzioni (1964), liderlik konusunu, karşısındakini etkileyebilme potansiyelini ifade eden bir ayrıcalık olarak açıklamıştır.

- Bass (1985) liderliği, grup hedeflerine ulaşmak adına grup çalışmasina etkide bulunmak olarak tanımlamıştır.

- Den Hartog ve Koopman (1997) liderliği; "bir hedefe ulaşmak amacyyla liderin yönlendirdiği gruba ait sosyal nüfus sürecidir" şeklinde ifade etmişlerdir.

Liderlik konusundaki tanımlarda, genellikle liderin uygulamasının esas alındığı ve tanımların bu yönde şekillendiği görülmektedir. Graen ve UhlBien (1995) ise, liderlik konusundaki farklı tanımlara ilişkin açıklamalarında; bir kavram veya olguyla ilgili tanımı yapılırken, kavramın etkileşimde bulunduğu diğer unsurlara göre konunun ve açıklamaların değişiklik gösterebileceği ve farklı sorunlara yönelik araştırmaların bu konuda belirleyici olduğunu öne sürmüşler $\urcorner$ ve liderlik, takipçi veya ilişki temelli bakış açıları olarak ifade etmişlerdir. Lider temelli bakış açısında liderlik özellikleri ön plandayken, takipçi temelli bakış açısında, takipçilerin özellikleri ve algıları önemlidir.

Liderlik; kişinin bir grubu sorgusuz sualsiz ardından sürükleyebilme yeteneğidir. Liderlik kavramı tıpkı öz yeterlilik ve iş tatmini kavramları gibi işletmeler için hayati önem taşımaktadır. Çünkü İşletme yöneticilerinin liderlik vasfını taşıması işletme amaçlarına ulaşmak için gerekli grup çalışmasını sağlayabilecek güçtür.

Liderler, etkisi altındaki grubun veya işletmenin amaçlarına ulaşması için birçok farklı rolü üstlenen kişilerdir. Bu açıdan liderin öncelikli görevi, insanların davranış ve tutumlarını görevlerin başarılması konusunda güdülemek, motive etmek ve organizasyonu sağlamaktır. Dış çevre ve koşullardaki değişim hızı dikkate alındığında, liderin bir önemli rolü de bu değişimlere ayak uyduracak kritik hamleleri yapmaktır. Zamanında yapılmayacak veya yanlış yapılacak hamlelerin ciddi sonuçları olacağını lider önceden sezinlemelidir. Lider aynı zamanda örgüt içi dinamikleri çok iyi takip edebilmelidir. Her bireyin farklı özelliklere sahip olduğu gerçeğinden hareketle, 
örgüt içindeki sorunlarda ve çözümle ilişkin uygulamaları örgüt içi barışı etkilemeyecek şekilde olmalıdır (Steers, 1991,s.374).

Dönüşümcü liderlik, problemlere farklı bakış acısı geliştiren, çalışanların mantık ve sezgilerini birlikte kullanmayı öğreten, insanları farklı bir birey olarak gören ve onların potansiyellerini en üst düzeye çıkarmaya çalışan bir liderlik stilidir (Buluç,2009).Etkileşimci liderlik dönüşümcü liderliğin tam tersi olarak ekonomik takas modeli çerçevesinde astların kısa vadeli fiziksel ve güvenlik ihtiyaçlarına odaklanır.(Koh.vd.1995).Etkileşimci liderliğin alt boyutlarını koşullu ödül,istisnalarla yönetim ve laissez fair gibi liderlik davranışları oluşturmaktadır (Buluç,2009).

\section{Literatür}

\section{Öz yeterlilik ve İş Tatmini Arasındaki İlişki}

Öz yeterlilik algılarının liderlik tarzı ilişkisinde iş tatminin aracılık rolünün varlığını ve bu kavramların birbirleriyle olumlu bir ilişki içerisinde olduğunu kanıtlamak için hazırlanan bu çalışmada bireylerin öz yeterliliği artıkça işten duyulan tatmininde arttığı yani aralarında doğru orantılı bir ilişki olduğu gözlenmiştir. Yazında birçok çalışmada bu iki kavram arasındaki ilişkinin pozitif yönde olduğunu gösteren sonuçlar elde edilmiştir. Öz yeterlilik ve iş tatmini arasındaki ilişkiyi inceleyen bu çalışmaların bazıları aşağıdaki gibi ifade edilmeye çalışılmıştır.

Erdoğdu (2009) tarafindan Osmaniye'de bulunan özel ve devlet hastanelerinde görev yapan personelin iş tatmini ve öz yeterlilikleri arasındaki ilişkiye yönelik bir çalışma yapılmıştır.(Araştırmaya 164 sağlık personeli katılmıştır.) Yapılan çalışmada, iki kavramı da etkileyen faktörler detaylı olarak araştırılmış ve incelenmiştir. Araştırma sonucuna göre; sağlık personelinde iş tatmininin orta seviyenin biraz üzerinde, öz yeterlilik düzeylerinin ise yüksek seviyede olduğu görülmüştür. Özel hastanelerde görev yapan personelin iş tatmininin daha yüksek olduğu görülürken öz yeterlilik düzeyleri üzerinde pozitif yönlü etkisinin bulunduğu, unvana faktörünün ise iş tatmini sağlanmasında ve öz yeterlilik düzeyinde herhangi bir etkisinin olmadığı belirtilmiştir.

Gençtürk ve Memiş (2010), devlet ve özel ilkokullarda çalışan öğretmenlerin öz yeterlik algıları ve iş doyumları arasındaki ilişkiyi demografik fak- 
törler üzerinden ölçmek amacıyla yaptıkları çalışmada; öğretmenlerin(705 öğretmen içerisinden basit tesadüfî örnekleme yoluyla evrenin yaklaşık \%53'ünü temsil edecek şekilde 373 öğretmen örnekleme alınmıştır.) öz yeterlik algılamalarında görev yaptıkları okullara göre değiştiği ve özel okullarda çalışan öğretmenlerde genel yeterliliğin devlet okullarında görev yapanlara oranla daha yüksek olduğunu belirtmişlerdir.

Gürbüz v.d. (2010) tarafından yapılan çalışmada, öz yeterliliğin çalışanlarda iş tatmini ve iş performansını artırmada olumlu bir etkisinin bulunduğu tespit edilmiştir. Ayrıca, temel benlik değerlendirmesinin iş tatminini açıllama gücünün, iş performansına göre daha fazla olduğundan bahsedilmiştir. Buluç ve Demir (2015) ilk ve ortaokul öğretmenlerinin öz yeterliklerine ilişkin algıları ile iş tatminleri arasındaki ilişkiyi incelemişlerdir. Araştırma sonuçlarına göre, öğretmenlerinin öz yeterlikleri ile iş tatminleri arasında anlamlı ve pozitif bir ilişki bulunmaktadır.

Turcan (2011) ilköğretim okulu öğretmenlerinde öz yeterlilik algılamaları ve iş tatminleri arasındaki ilişkiyi incelemişlerdir. Çalışma sonucunda öğretmenlerinin genelde öz yeterlilik seviyelerinin yüksek olduğu belirlenmiştir. Ayrıca öğretmenlerinin öz yeterlik algılarıyla iş tatminleri arasında pozitif ve anlamlı bir sonuç bulunmuştur. Bu sonuca göre öğretmenlerde öz yeterlik algısı arttıkça iş tatmini düzeyi de yükselmektedir.

Durmaz ve Ören (2017),Öz Yeterlilik ve Özgüvenin İşgücü ve İstihdama Etkisine Bir Bakış adlı çalışmasına göre; Bireylerin işgücü piyasasına hazırlandığı eğitim süreçlerinde ya da çalıştıkları süre zarfında, özgüven ve öz yeterliliklerini arttırıcı politikaların ve teşviklerin izlenmesi bu bireylerden elde edilecek verimliliği, motivasyonu, iş tatmini ve iş bağlılığını arttıracaktır. İşverenlerce ya da devletçe izlenecek politikalarda istihdamı sadece sayıca arttırıcı yöntemler yerine bu değişkenleri arttırıcı yöntemlerin uygulanması hem sayısal olarak hem de niteliksel olarak işgücü piyasasının güçlenmesini sağlayacaktır.

\section{Liderlik ve İş Tatmini Arasındaki İlişki}

(Bass, 1985) liderlik konusundaki çalışmaları sonucunda; özellikle dönüştürücü liderlik tarzının, çalışanlarda motivasyon sağlanmasında diğer liderlik türlerine göre daha etkili olduğunu, dolayısıyla liderlik tarzlarının çalışanların iş tatmini üzerinde de pozitif bir etkisinin bulunduğundan bahsetmiş- 
tir. Medley ve La Rochelle (1995) çalışmalarında, uygulanan ve algılanan liderlik tarzlarının iş tatmini üzerinde çok önemli bir etkisinin bulunduğunu belirtmişlerdir. Medley ve La Rochelle, literatürdeki diğer çalışmalarda belirtildiği gibi iş tatminini etkileyen en önemli liderlik sitilinin dönüşümcü liderlik olduğunu söylemişlerdir.

Sang Long Choi ve arkadaşlarının (2016), Dönüşümsel liderlik, yetkilendirme ve iş tatmininde yetkilendirmenin aracılık rolünün olduğunu kanitlamak amacıyla yapılan çalışmaya Malezya'da bir devlet hastanesinde ve büyük bir özel hastanede çalışan 200 hemşire katılmıştır. Araştırmanın sonucuna göre yetkilendirmenin, dönüşümcü liderliğin iş tatmini üzerindeki etkisine aracllık ettiği saptanmıştır.

Çalışanların güçlendirilmesi yani yetkilendirilmesi sadece iş tatmini için çok önemli bir unsur değildir. Yetkilendirme, ayn zamanda hemşireler arasında dönüşümsel liderlik ile iş tatmini arasındaki ilişkiye aracllı etmektedir.

Emery ve Barker (2007) hizmet sektöründe çalışan personel üzerinde yaptıkları çalışmada, liderlik stillerinin birçoğunun iş tatmin üzerinde anlamlı ve pozitif bir etkiye sahip olduğunu belirtmişlerdir. Baltacı v.d (2014) Alanya'da turizm sektöründe çalışan personelin iş tatmin düzeylerinde yöneticilerin liderlik özelliklerinin ne şekilde etkilediğini araştırmışlardır. Araştırma sonucuna göre çalışanların vizyoner ve dönüşümcü liderlik algilarının iş tatminini etkileyen ne önemli liderlik stilleri olduğu ve regresyon analizi sonuçlarına göre liderlik tarzlarının çalışanların iş tatminleri üzerinde $\% 58$ 'lik bir etkiye sahip olduğundan bahsedilmiştir.

Sedat Çelik(2015) ve arkadaşlarının otel işletmelerinde etik liderlik tarzının örgütsel bağlllık ve iş tatmini üzerindeki etkisini araştırmak için yaptıkları çalışmanın sonucuna göre (çalışmaya Antalya'daki 4 ve 5 yıldızlı otel işletmelerinde çalışan 391 kişi katılmıştır.) etik liderliğin örgütsel bağlıllığın iş tatmini üzerinde etkili olduğu ve yine etik liderliğin örgütsel bağlllık ve iş tatmini üzerinde etkisi olduğu saptanmıştır.

\section{Öz Yeterlilik ve Liderlik Kavramları Arasındaki İlişki}

Köksal (2008) tarafından antrenörlerde liderlik tarzı ve öz yeterlilik ilişkisi konusunda yapılan çalışmada;(çalışmaya 324 antrenör katılmıştır.) liderlik uygulamalarının eğitim-öğretim davranışı hariç öz yeterlilik üzerinde 
önemli bir etkisinin bulunmadığı ve öz yeterliğin yaşla doğrusal orantılı olarak arttı̆̆ından bahsetmiştir. Çalışmada, özellikle tecrübeli antrenörlerde demokratik liderlik stilinin daha çok benimsendiğini ve söz konusu kişilerde öz yeterlilik seviyesinin diğer antrenörlere oranla daha yüksek olduğunu görülmüştür.

Toklu (2010) Tenis antrenörlerinde liderlik özellikleri ve uygulamaların öz yeterlilik üzerindeki etkisinin belirlenmesi amacıyla yaptı̆̆ı çalışmada, antrenörlerin(araştırmaya 177 antrenör katılmıştır.) öz yeterlilikleri ve ödüllendirici liderlik özelliği arasında negatif bir ilişkiden bahsedilmiştir. Bu ilişkide antrenörlerin öz yeterlilik durumu artarken ödüllendirici liderlik özelliği azalıyor veya öz yeterlilik durumu azalırken ödüllendirici liderlik özelliğinin arttığı tespit edilmiştir. Akgündüz (2012) otel çalışanlarında otantik liderlik ve öz yeterlilik arasındaki ilişki şehirve resort otellerinde çalışan personel açısında incelemiştir.(Araştırmanın örneklemi 175 kişi oluşturmaktadır.) Araştırma sonuçlarına göre; şehir otellerinde çalışan personelin, resort otellerde görev yapan personele oranla otantik liderliğe daha olumlu baktıkları görülmektedir. Bu nedenle otantik liderliğin öz yeterlilik üzerinde pozitif bir etkinin bulunduğunu belirlenmiştir.

\section{Öz Yeterlik, Liderlik ve İş Tatmini Arasındaki İlişki}

Shuang Ren ve Doren Chadee tarafindan ("Ethical Leadership, Self-Efficacy And Job Satisfaction İnchina: The Moderating Role Of Guanxi",) 2017 yılında yapılan araştırmanın amacı çalışanların liderlerinin etik davranışlarına ilişkin algılarının Çin'deki işyeri kültüründe iş tatminlerini nasıl etkilediğini araştırmaktır. Hazırlamış olduğumuz araştırmayı ilgilendiren sonuçlarından biri öz yeterliliğin etik liderlik-iş tatmini ilişkisine pozitif ve güçlü bir şekilde aracllık ettiğidir.

\section{Araştırmanın Hipotezler}

Öz yeterlilik, liderlik tarzları ve iş tatmini konusunda ilgili literatür incelendikten sonra araştırmanın hipotezleri aşağıdaki gibi belirlenmiştir;

- H1: Liderlik Tarzının Öz yeterlilik Üzerinde Etkisi Vardır.

- H2: Liderlik Tarzının İş Tatmini Üzerinde Etkisi Vardır. 
- H3: Öz yeterlilik Algısının Liderlik Tarzı ilişkisinde, İş Tatmininin Aracılık Rolü Vardır.

\section{Araştırmanın Metodolojisi}

\section{Araştırmanın Amacı ve Yöntemi}

$\mathrm{Bu}$ araştırmanın amacı, AVM'lerde çalışan personelin, öz yeterlilik algısının liderlik tarzı ilişkisinde, iş tatminin aracılık rolünü tanımlayan bir model oluşturmak ve test etmektir. Oluşturulan modele göre; çalışanların öz yeterliliklerine etki eden liderlik ilişkisinde, aracilık rolü olarak iş tatminin kattlımını ölçen yapısal eşitlik modeli oluşturulmuş ve bu şekilde aralarındaki ilişkinin durumu bir istatistik programı aracılığıyla test edilmiştir.

\section{Araştırmanın Örneklemi}

Araştırma, Balıkesir Edremit Bölgesinde bulunan AVM'lerde faaliyet gösteren, 15 kurumsal firmada çalışan personel üzerinde gerçekleştirilmiştir. Çalışma için 250 anket dağıtılmış ve geçerli kabul edilen 201 anket uygulama konusu yapılmıştır. Çalışmada veri seti olarak 5'li likert tipi anket yönetim kullanılmıştır. Anketin birinci bölümünde demografik ve tanımlayıcı bilgiler, ikinci bölümünde ise, Schwarzer ve Jarusalem tarafından 1979 yllında Almanya'da geliştirilen, 1981 yılında yapılan düzeltmelerle 10 maddeye indirilen ve 1995 yılında son haline getirilerek, İngilizce de dâhil olmak üzere 28 dile çevirisi yapılan 10 maddelik öz yeterlik ölçeği, Avalio ve Bass (2000) tarafından geliştirilen, Yurtkoru (2001) tarafından Türkçeye çevrilen 36 maddelik çok faktörlü liderlik (MLQ) ölçeği kullanılmıştır. Çok faktörlü liderlik ölçeğinin ilk 20 sorusu dönüşümcü liderlik, son 16 sorusu ise etkileşimci liderlik tarzına yöneliktir. Anketin son kısımda Weiss, Dawis, England ve Lofquist (1967) tarafından geliştirilen 20 soruluk “İş Tatmini Ölçeği” kullanılmıştır.

\section{Verilerin Analizi}

Tanımlayıcı İstatistikler: Araştırmaya katılanlara ilişkin demografik veriler incelendiğinde; \%57,7'sinin kadın, \%45,3'ünün erkek, söz konusu kişilerin \%79,1'inin 18-35 yaş aralığında ve \%61,5'inin bekâr olduğu görülmektedir. 
Aynı iş yerinde çalışma süresi genellikle 1-5 yıl ( $\% 68,7)$ arasında olup, kat1lımcların büyük çoğunluğunun $(\% 46,3)$ lise mezunu, normal çalışan $(\% 74)$ ve \%52,7'sinin maaşının 1500-2500 lira olduğu tespit edilmiştir. Bu konu hakkında genel bir değerlendirme yapılırsa; AVM'lerde görev yapan personelin çoğunluğunun bayan, çalışma yaş aralığının genç, bu duruma bağlı olarak büyük bir kısmının bekâr olduğu ve eğitim seviyelerinin yüksek olmadığı, birçoğunun asgari ücret seviyesinde maaş aldıkları ve aynı iş yerinde uzun süre çalışmadıkları söylenebilir.

Tablo 1. Tanımlayıcı İstatistikler

\begin{tabular}{llllll}
\hline \multicolumn{1}{l}{ Faktörler } & Ortalama & S.S. & Çarpıklık & Basıklık \\
\hline \multicolumn{2}{l}{ Öz Yeterlilik } & 3,8264 &, 71495 &,- 962 & 1,389 \\
\hline \multirow{2}{*}{ Liderlik } & Dönüşümcü & 3,6565 &, 81894 &,- 918 & 1,179 \\
\cline { 2 - 6 } Tarzı & Etkileşimci & 3,2254 &, 60954 &,- 033 &,- 334 \\
\hline İş Tatmini & 3,5112 &, 70490 &,- 524 &, 155 \\
\hline
\end{tabular}

Anket sorularının istatistik programıla analizi sonucunda ilk olarak kayıp veya eksik veri olup olmadığı ile soruların dağılımı incelenmiştir. Tablo 1 'de yer alan bilgilerde de görüldüğü üzere, verilerin basıklık ve çarpıklık değerleri normal değer aralığ 1 kabul edilen $+1,5$ ila $-1,5$ arasındadır. Normal dağılıma bağlı olarak değişkenler arasında ilişki ve etki analizlerinin yapılabileceği görülmektedir.

\section{Faktör Analizine İlişkin Bulgular}

Barlett Küresellik Testi, araştırmada kullanılan değişkenler arasında ilişki düzeyini göstermektedir. Değişkenler arasında faktör analizi yapılması için söz konusu testin anlamlılık değerinin 0,05 'den küçük olması gerekmektedir. Aynı şekilde 0 ile1 arasında değerler alarak değişkenler arasındaki ilişkinin faktör analizine uygunluğunu test eden KMO değerinin de 1'e yakın olması, faktör analizi için önemlidir (Durmuş vd., 2013; 80). Araştırmadaki değişkenler için yapılan analizinde KMO ve Barlett Küresellik Testi sonuçlarının tamamında $p$ değerini 0,05 'den küçük ve $\mathrm{KMO}$ değerini ise 1'e yakın olduğu görülmüş olup, değişkenlere ait verilere faktör analizi uygulanmıştır. 
Tablo 2. Öz Yeterlilik Ölçeği Faktör Analizi ve Güvenilirlik Katsayısı

\begin{tabular}{lrc}
\hline Faktörler & $\begin{array}{r}\text { Faktör } \\
\text { Yükleri }\end{array}$ & $\begin{array}{c}\text { Cronbach's } \\
\text { Alpha }\end{array}$ \\
\hline Yeterince çaba harcarsam, zor sorunları çözmenin bir yolunu daima bulabilirim. &, 756 \\
\hline $\begin{array}{l}\text { Bana karşı çıkıldığında, istediğimi elde etmemi sağlayacak bir yol ve yöntem } \\
\text { bulabilirim. }\end{array}$ &, 703 \\
\hline Amaçlarıma bağlı kalmak ve bunları gerçekleştirmek benim için kolaydır. &, 755 \\
\hline Beklenmedik olaylarla etkili bir biçimde başa çıkabileceğime inanyorum. &, 834 \\
\hline $\begin{array}{l}\text { Yeteneklerim sayesinde beklenmedik durumlarla nasıl baş edebileceğimi biliyo- } \\
\text { rum. }\end{array}$ &, 840 \\
\hline Gerekli çabayı gösterirsem, birçok sorunu çözebilirim. &, 782 \\
\hline $\begin{array}{l}\text { Baş etme gücüme güvendiğim için zorluklarla karşılaştı̆̆ımda, genellikle birkaç } \\
\text { çözüm yolu bulabilirim. }\end{array}$ &, 818 \\
\hline Bir sorunla karşışlaştı̆ımda, genellikle birkaç çözüm yolu bulabilirim. &, 823 \\
\hline Başım dertte olduğunda, genellikle bir çözüm düşünebilirim. &, 779 \\
\hline Önüme çkan zorluk ne olursa olsun, üstesinden gelebilirim. &, 737 \\
\hline
\end{tabular}

Öz yeterlilik değişkenine ait analizdeki faktörler ağırlıkları; 0,703 ile 0,840 arasında değişmektedir. Ölçeğin güvenlik değeri 0,930 olarak tespit edilmiştir.

Tablo 3. Liderlik Ölçeği Faktör Analizi ve Güvenilirlik Katsayısı

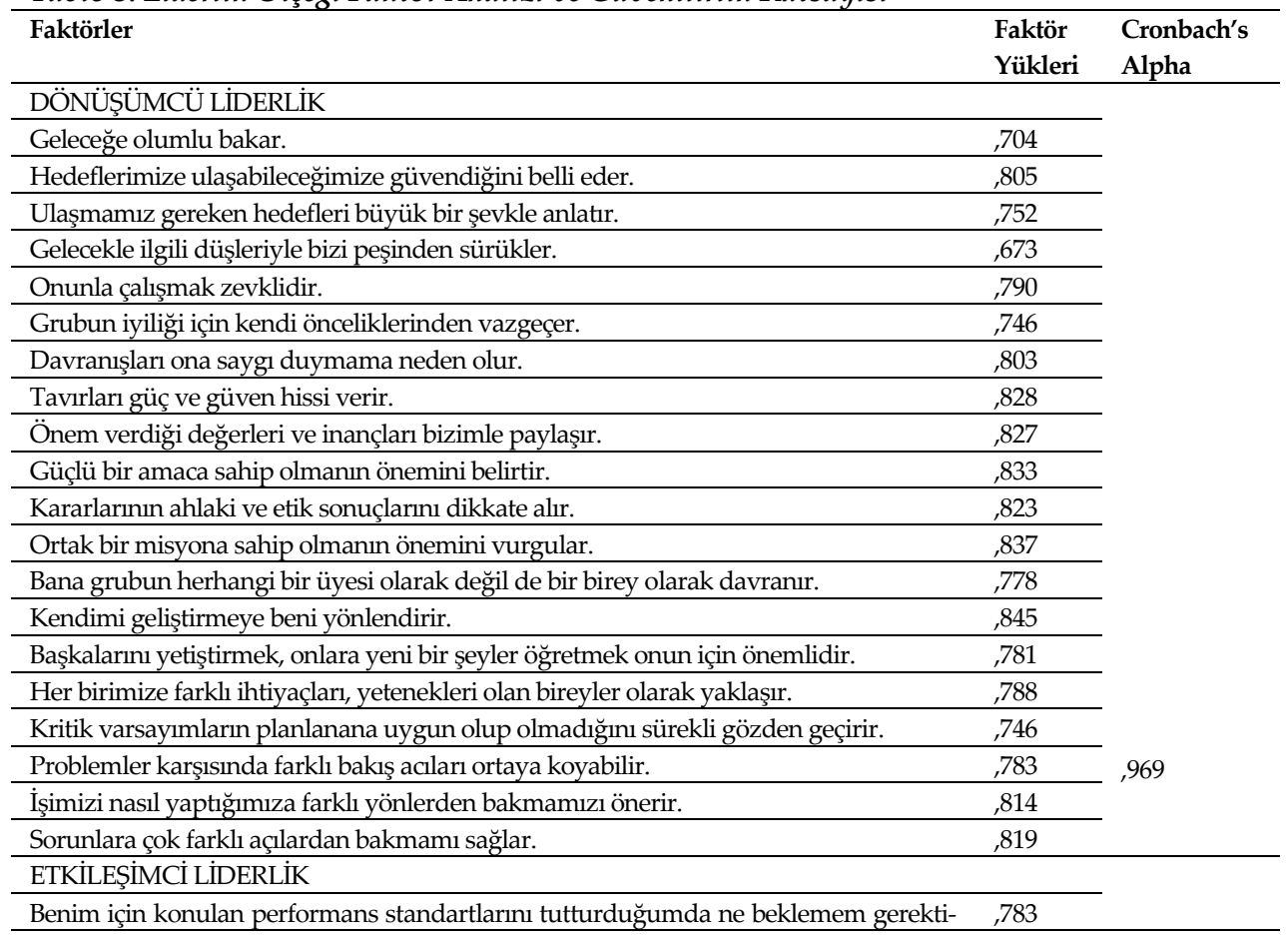




\begin{tabular}{lc}
\hline ğini açıça söyler. &, 809 \\
\hline Harcadığım çabayı ve hevesi gördüğünde bana destek olur. &, 763 \\
\hline Performans hedeflerimize ulaştığımızda uygun şekilde ödüllendirilmemizi sağlar. &, 774 \\
\hline Yapılan iyi işi daima takdir eder. &, 644 \\
\hline Hatalarımız konusunda bizi daima uyarır. &, 567 \\
\hline Zamanını "söndürülecek yangınlar" arayarak geçirir. &, 697 \\
\hline Yaptı̆̆ım hataları asla unutmaz. &, 631 \\
\hline Hedefe ulaşmadaki başarısızlıklar asla gözünden kaçmaz. &, 595 \\
\hline Sorunlar ciddiyet kazanıncaya kadar karışmaz. &, 786 \\
\hline Harekete geçmesi için işlerin kötüye gitmiş olması gerekir. &, 789 \\
\hline Mecbur kalmadıkça tedbir almanın gereksizliğine inanır. &, 786 \\
\hline Harekete geçmesi için problemlerin kronikleşmesi gereklidir. &, 776 \\
\hline Önemli bir konu karşısında karışmaktan çekinir. &, 753 \\
\hline Gerektiğinde ortada yoktur. &, 799 \\
\hline Karar vermekten kaçınır. &, 722 \\
\hline Acil sorulara cevap vermeyi geciktirir
\end{tabular}

Liderlik tarzlarına ait analizdeki faktörler ağırlıkları dönüşümcü liderlik için 0,673 ile 0,845 arasında ve ölçek güvenlik değeri 0,936 olarak, etkileşimci liderlik içinse 0,567 ile 0,809 arasında ve ölçek güvenlik değeri 0,826 olarak tespit edilmiştir.

Tablo 4. İş Tatmini Ölçeği Faktör Analizi ve Güvenilirlik Katsayısı

\begin{tabular}{|c|c|c|}
\hline Faktörler & $\begin{array}{l}\text { Faktör } \\
\text { Yükleri }\end{array}$ & $\begin{array}{l}\text { Cronbach's } \\
\text { Alpha }\end{array}$ \\
\hline Beni her zaman meşgul etmesi bakımından & ,730 & \multirow{20}{*}{941} \\
\hline Tek başıma çalışma olanağımın olması bakımından & ,763 & \\
\hline Ara sıra değişik şeyler yapabilme şansımın olması bakımından & 671 & \\
\hline Toplumda saygın bir kişi olma şansını bana vermesi bakımından & 772 & \\
\hline Yöneticimin astlarını yönetme tarzı açısından & ,782 & \\
\hline Yöneticimin karar vermedeki yeteneği bakımından & ,758 & \\
\hline Vicdanıma aykırı olmayan şeyleri yapabilme şansım olması açısından & 677 & \\
\hline Bana sabit bir iş sağlaması bakımından & ,617 & \\
\hline Başkaları için bir şeyler yapabilme olanağına sahip olmam bakımından & ,793 & \\
\hline Kişilere ne yapacaklarını söyleme şansımın olması bakımından & ,750 & \\
\hline Kendi yeteneklerimi kullanarak bir şeyler yapabilme şansımın olması bakımından & ,781 & \\
\hline İş ile ilgili alınan kararların uygulanmaya konulması bakımından & ,712 & \\
\hline Yaptığım iş ve karşılığında aldığım ücret bakımından & 653 & \\
\hline İş içinde terfi olanağımın olması açısından & ,757 & \\
\hline Kendi kararlarımı uygulama serbestliğini bana vermesi bakımından & ,802 & \\
\hline İşimi yaparken kendi yöntemlerimi kullanabilme şansını bana sağlaması açısından & ,736 & \\
\hline Çalışma şartları bakımından & ,751 & \\
\hline Çalışma arkadaşlarımın birbirleri ile anlaşmaları bakımından & ,748 & \\
\hline Yaptı̆̆ım iyi bir iş karşısında takdir edilmesi açısından & ,785 & \\
\hline Yaptığım iş karşısında duyduğum başarı hissinden & ,771 & \\
\hline
\end{tabular}


İş tatmini faktör analizinde faktörler ağırlıkları; 0,617 ile 0,802 arasında değişmektedir. Ölçeğin güvenlik değeri 0,941 olarak tespit edilmiştir.

\section{Korelâsyon Analizi}

Değişkenler arasında ilişkinin tespit edilmesi amacıyla korelasyon analizi yapılmış ve sonuçlar tablo 1'de verilmiştir.

Tablo 5. Korelâsyon Analizi

\begin{tabular}{llllll}
\hline \multirow{2}{*}{ Faktörler } & Korelâsyon & & \\
\cline { 2 - 5 } & $\mathbf{1}$ & $\mathbf{2}$ & $\mathbf{3}$ & $\mathbf{4}$ \\
\hline \multirow{2}{*}{ Öz Yeterlilik (1) } & 1,000 & $0,638^{* *}$ & 0,100 & $0,203^{* *}$ \\
\hline \multirow{2}{*}{ Liderlik Tarzı } & Dönüşümcü (2) & $0,638^{* *}$ & 1,000 & $0,327^{* *}$ & $0,561^{* *}$ \\
\cline { 2 - 5 } & Etkileşimci (3) & 0,100 & $0,327^{* *}$ & 1,000 & $0,338^{* *}$ \\
\hline \multirow{2}{*}{ İş Tatmini (4) } & $0,203^{* *}$ & $0,561^{* *}$ & $0,338^{* *}$ & 1,000 \\
\hline
\end{tabular}

${ }^{* *} p<0,01$

Korelâsyon analizinden; öz yeterlilik ve dönüşümcü liderlik arasında $(\mathrm{r}=0,64)$ iyi derecede ve pozitif yönde bir ilişki olduğu, öz yeterlilik ve iş tatmin arasında $(\mathrm{r}=0,20)$ düşük seviyede pozitif bir ilişki bulunduğu görülmüştür. Dönüşümcü liderlik ile iş tatmin arasında $(\mathrm{r}=0,56)$ orta seviyede pozitif bir ilişkinin varlığ , Etkileşimci liderli ve iş tatmini arasında $(\mathrm{r}=0,33)$ düşük seviyede pozitif bir ilişki olduğu tespit edilmiştir. Diğer taraftan Öz yeterlilik ve etkileşimci liderlik arasında istatistiksel olarak anlamlı bir ilişki tespit edilememiştir. Bu şekilde değişkenler arasındaki korelasyon katsay1ları, araştırmanın genel modelinin kurulması açısından olumludur.

\section{Doğrulayıcı Faktör Analiz}

Sosyal bilimlerde analiz amaçlı yapılan ölçümlerde en çok başvurulan yöntemlerden birisi de doğrulayıcı faktör analizidir. Doğrulayıcı faktör analizi (DFA), gözlenen değişkenler ile gizil değişkenler (faktörler) arasındaki ilişkiyi ortaya koyan ve araştırma kapsamında belirlenen hipotezlerin test edilmesi amacıyla kullanılan bir tekniktir. Doğrulayıcı faktör analizinde ilk yapılması gereken şey teorik bir temele oturtulan modelin oluşturulmasıdır. Modelin uyum iyiliğinin değerlendirilmesinde, değişkenler arasındaki ilişkileri ortaya koyan istatistiksel verilere bakılmaktadır. Bu istatistiklerden Ki- 
kare istatistiğinin serbestlik derecesine bölünmesinde, $\chi 2 / \mathrm{df}<2$ ise ortaya çıkan sonuç mükemmel uyumu, $\chi 2 / \mathrm{df}<3$ ise kabul edilebilir bir uyumu işaret etmektedir. Diğer taraftan, uyum iyiliği indeksi (GFI) ve karşılaştırmalı uyum indekslerinin (CFI), 1'e yakın olması, $(\mathrm{p}<0,10)$ yani 0,90 ve üzeri değerler kabul edilir uyumu gösterir. Yaklaşık hataların ortalama karekökünün (RMSEA) ise 0,10'a kadar kabul edilebilir uyumu göstermektedir ( Aytaç ve Öngen, 2012; 17). Çalışmada, belirlenen modelin analizinden önce kullanılan her bir değişken için doğrulayıc faktör analizi yapılmış ve sonuçlar tablo 2'de gösterilmiştir.

Tablo 6. Değişkenlere İlişkin Doğrulayıcı Faktör Analizi

\begin{tabular}{llllllll}
\hline Faktörler & $\chi^{2} / \mathrm{df}$ & $\mathrm{P}$ & AGFI & GFI & CFI & NFI & RMSEA \\
\hline Öz Yeterlilik & 2,027 &, 000 &, 898 &, 939 &, 973 &, 948 &, 071 \\
\hline Liderlik Tarzl & 1,691 &, 000 &, 818 &, 866 &, 964 &, 928 &, 059 \\
\hline İş Tatmini & 1,614 &, 000 &, 873 &, 913 &, 967 &, 917 &, 055 \\
\hline
\end{tabular}

Değişkenlerin doğrulayıcı faktör analizi sonucunda, $\chi 2 / \mathrm{df}$ derecesi her üç faktör içinde çok iyi sayılabilecek bir seviyede olduğu, CFI değerinin tüm değişkenlerde ve GFI değerlerlerinin ise liderlik hariç 0,90'ı üzerinde olduğu görülmektedir. Genel itibariyle modelde kullanılacak değişkenlerin tamamının uyum analizlerinin çok iyi olduğu söylenebilir. 


\section{Araştırma Modeli ve Hipotezlerin Testi}

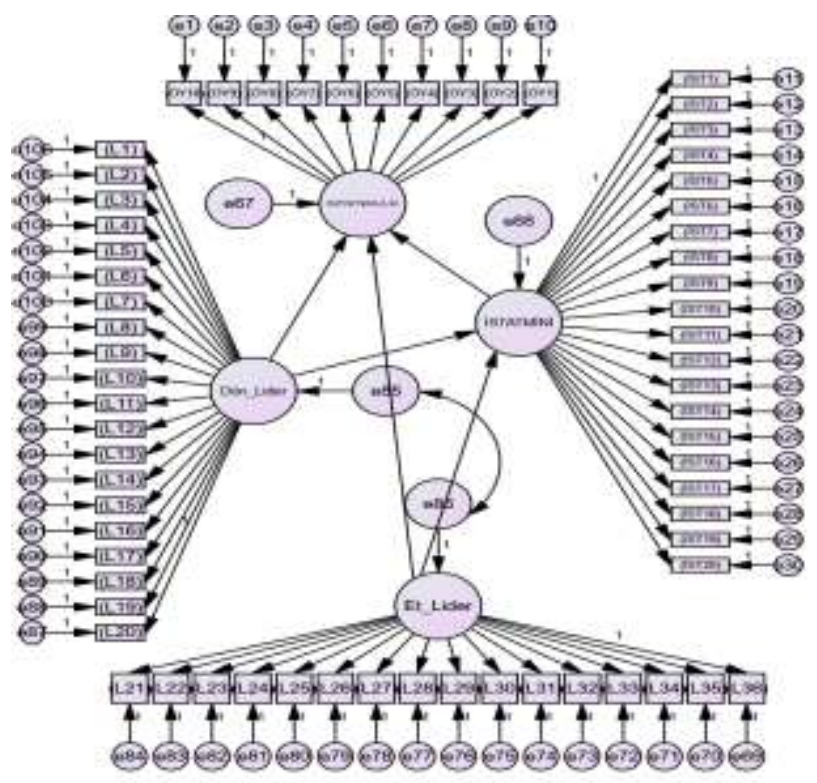

Şekil 1. Öz yeterlilik, Liderlik Tarzı ve İş Tatmini Arasındaki İlişkinin Yapısal Eşitlik Modellemesi

Araştırmanın amacı doğrultusunda çizilen teorik model, şekil 1'deki gibi oluşturulmuş ve söz konusu modele ait hipotezlerin test edilmesi için çoklu regresyon analizi yapılmıştır.

Tablo 7. Çoklu Regresyon Analizi

\begin{tabular}{|c|c|c|c|c|c|c|c|c|}
\hline & $\begin{array}{l}\text { Bağımsız } \\
\text { Değişken }\end{array}$ & $\begin{array}{l}\text { Bağımlı } \\
\text { Değişken }\end{array}$ & $\mathbf{R}^{2}$ & $\begin{array}{l}\text { Tah. Std. } \\
\text { Hatası }\end{array}$ & $\beta$ & $\mathbf{F}$ & $\mathbf{P}$ & DW \\
\hline Model 1 & Liderlik T.** & İş Tatmini & ,330 & ,57564 &, 577 & 99,901 &, $000^{*}$ & 1,561 \\
\hline Model 2 & Liderlik T. ${ }^{* *}$ & $\begin{array}{l}\text { Öz } \\
\text { Yeterlilik }\end{array}$ & ,275 & 62704 & ,528 & 77,425 &, $000^{*}$ & 1,930 \\
\hline Model 3 & Liderlik T.** & $\begin{array}{l}\text { İş Tatmini } \\
\text { Öz Yeterlilik }\end{array}$ & ,597 & ,42298 & $\begin{array}{l}, 450 \\
, 547\end{array}$ & 103,330 &, $000^{*}$ & 1,916 \\
\hline
\end{tabular}

*p<0,05 **(Dönüşümcü ve Etkileşimci Liderlik Ort)

Tablo 7'de öz yeterlilik, liderlik tarzı ve iş tatmini arasındaki ilişkiye ait etkilerin ölçülmesi için yapılan regresyon analizi sonuçları bulunmaktadır. 
Model 1'de Liderliğin iş tatmini üzerindeki etkisini ölçülmüş ve model anlamlı bulunmuştur ( $F=99,901)$. Değişkenler arasındaki anlam boyutu $(\beta=, 577$ $p<0,05)$ ve etki oranı $R^{2}=0,33$ olarak gerçekleşmiştir. Bu sonuçlara göre liderlik tarzının iş tatmini üzerinde pozitif anlamlı bir etkisi vardır ve H1 kabul edilmiştir. Model 2'de ise liderlik tarzının öz yeterlilik üzerindeki etkisi test edilmiştir. Model anlamlı $(F=77,425)$, anlam boyutu $(\beta=, 528 p<0,05)$ ve etki oranı $R^{2}=0,275$ olarak bulunmuştur. Ortaya çıkan sonuçlar liderlik tarzının öz yeterlilik algılamalarında pozitif bir etkiye sahip olduğunu işaret etmekte olup, bu şekilde araştırmanın ikinci hipotezi de (H2) kabul edilmiştir.

Araştırmanı ana modelini oluşturan, liderlik tarzlarının öz yeterliliğe etkisinde iş tatmininin aracıllk rolüne ilişkin regresyon verileri tablo $7^{\prime}$ nin son bölümünde verilmiştir. Model 3'e ait veriler incelendiğinde liderlik tarzı, öz yeterlilik ve aracı değişken olarak iş tatmini ilişkisinde model anlamlıdır ( $F=103,330)$. Liderlik tarzı, öz yeterlilik arasındaki 0,528 olan anlam boyutu iş tatminin aracllık rolü ile 0,547'ye yükselmiştir. Bu duruma paralel olarak aracılık etkisi ile birlikte öz yeterliliğin liderlik tarzından etkilenme oranı da $\left(R^{2}\right)$ 0,275'ten 0,597'ye yükselmiştir. Bu sonuçlara göre ana hipotez olan, “H3: Öz yeterlilik Algısının Liderlik Tarzı ilişkisinde, İş Tatmininin Aracılık Rolü Vardır." Kabul edilmiştir.

\section{Sonuç}

$\mathrm{Bu}$ araştırmada, çalışanlarının öz yeterlilik algılamalarını etkileyen liderlik tarzlarında aracı etki olarak iş tatminin rolünün bulun bulunmadığı araştırılmıştır. Bu kapsamda; araştırma Balıkesir Edremit İlçesinde faaliyet gösteren AVM çalışanları üzerinden yapılmıştır. Mağazacılık sektörünün yapısı gereği katılımcıların çoğunluğu eğitim seviyeleri düşük, asgari ücret civarında maaş alan, genç ve bekâr bayanlardan oluştuğu görülmüştür. Araştırmada öncelikle kavramlar açıklanmış, literatür taraması yapılmış ve geçmiş çalışmalardaki bulgular incelenmiştir. Uygulama kısmında ise araştırma için hazırlanan ve dağıtılan anket formlarında geçerli kabul edilen 201 anket, araştırmada veri seti olarak kullanılmıştır. Araştırmada değişkenler için uygulanan korelasyon analizinde, dönüşümcü liderliğin hem iş tatminin hem de öz yeterlilik üzerinde anlamlı bir ilişkisi olduğu tespit edilirken, etkileşimci liderliğin iş tatmini üzerinde düşük, öz yeterlilik üzerinde ise herhangi bir etkisinin bulunmadığ görülmüştür. Bu sonuçlar üzerinden 
değişkenlerin etkileşimini test etmek amacıyla araştırmada çoklu regresyon analizi uygulanmıştır.

Araştırmanın birinci hipotezi olan liderlik tarzının iş tatminine etkisi konusunda yapılan regresyon analizinde, genel liderlik tarzındaki olumlu bir değişimin iş tatminini pozitif olarak 0,330 birim artırdığı görülmüştür. Literatürde bu konudaki diğer çalışmalardan; Tutar v.d. (2006) özellikle dönüşümcü liderliğin, çalışanlarda iş tatminini ciddi oranda artırdığını ve bu tip liderlerle çalışanlarda işten ayrılma niyetinin düşük olduğundan bahsedilmiştir. Chiok (2001) liderlik davranışlarının iş tatmini üzerinde \%29'luk pozitif bir etkiye sahip olduğunu, Koçak ve Özüdoğru (2015) ise yöneticilerde liderlik uygulamaları ile çalışanların iş tatmini üzerinde pozitif ve güçlü bir ilişki olduğunu tespit etmişlerdir. Tüm bu çalışmaların araştırma hipotezi bulguları ile örtüştüğü görülmektedir.

Liderlik tarzının öz yeterlilik üzerindeki etkisinin araştırıldığı ikinci hipotezde, değişkenler arasında pozitif ve anlamlı bir ilişki tespit edilmiştir. Bu sonuca göre Liderlik tarzındaki bir birimlik değişimin öz yeterlilik alg1sını 0,275 birim artırmaktadır. Man (2011) tarafından yapılan araştırmada çalışanların liderlik algılamaları ile öz yeterlilikleri arasında anlamlı ve pozitif bir ilişki bulunduğundan bahsedilmiştir. Yine Choi v.d.(2003) dönüşümcü liderlik tarzı ile öz yeterlik arasında pozitif anlamlı bir ilişki bulunduğunu belirtmişlerdir. Literatürdeki ilgili çalışmalarda da görüldüğü üzere liderlik tarzı algılamalarının çalışanların öz yeterlilik üzerinde olumlu bir etkiye sahiptir.

Araştırmanın ana ve son hipotezinde ise liderlik tazı öz yeterlilik ilişkisinde iş tatminin aracılık rolünün düşük seviyede de olsa pozitif ve anlamlı olduğu görülmüş̧ür. Liderlik tarzı, öz yeterlilik arasındaki 0,528 olan anlam boyutu iş tatminin araclılk rolü ile birlikte 0,547'ye yükselmiştir. Bu etkiye bağlı artıştaki ana sebebin, liderlik tazı algılamalarının hem öz yeterlilik hem de iş tatmini üzerindeki pozitif etkisinden kaynaklandığı söylenebilir. Yani olumlu ve uyumlu liderlik uygulamaları çalışan personele diğer değişkenler üzerinden (motivasyon, performans v.b.) katma değerli olarak etki etmektedir. Ancak etkinin düşük olmasının sebebinin dönüşümcü ve etkileşimci liderliğin analizde bir bütün olarak ele alınmasında, etkileşimci liderliğin düşük korelasyon katsayısının dönüşümcü liderliğe etki etmesi olarak açıklanabilir. Liderlik tazı öz yeterlilik arasındaki ilişkiye iş tatminin katılımı ile yapılmış herhangi bir çalışmaya literatürde rastlanılmamıştır. Bu nedenle 
araştırma amacının ve sonuçlarının literatüre bu konuda önemli bir katkıda bulunacağı söylenebilir.

Çalışmanın özellikle belirli ve dar bir çevrede yapılmış olması araştırmanın en büyük kısıtını oluşturmaktadır. Diğer taraftan bu ve benzeri çalışmaların tek bir sektör yerine farklı sektörlerin de araştırma dâhil edilerek karşılaştırmalı sonuçlar üzerinden yorumlanmasının sonuçların genellenmesi açısından daha uygun olacağı düşünülmektedir. 


\title{
EXTENDED ABSTRACT
}

\section{The Intermediate Role Of Job Satisfaction In Relationship Between Self-Quality Perception And Leadership Style \\ *}

\author{
Edip Örücü - Cemile Şeker - Attila Kaya \\ Onyedi Eylül University, Osmaniye Korkut Ata University
}

For organizations, the concept of leadership is the secret of success. Leadership, which is widely used in the literature, is closely related to many concepts. A manager who also works in the business must have leadership qualities, especially for senior business officials to have these qualities is vital for the future of the business. The quality of the relationship is equally important. Due to its complex nature, human beings are difficult to understand and understand. It would be a big mistake to think that he will always be rational.

The quality of communication between the leader and the subordinate directly affects the efficiency and quality of the work done. It is the equivalent of the concept of effectiveness and efficiency for both the company and the company by doing the job lovingly. As it is known, the suitability of the job to the person is defined as ergonomics. It is actually a concept that enters ergonomics in the satisfaction of the person with his self-efficacy in his work.

There are many internal and external factors that affect self-efficacy perceptions in employees, and one of these factors is leadership. The leader is the person who has a direct effect on the staff with their behavior and practices. In addition, the relationship between these two elements in the organizational structure; Various factors such as organizational culture, motivation and job satisfaction also have direct or indirect effects.

Self-efficacy, that is, fulfilling the requirements of one's self-belief business, will not only be a determining factor on the road to their own goals and career plans, but will also enable the business to reach its goals. In this study, which was prepared to prove the existence of the mediating role of job satisfaction in the leadership style relationship of self-efficacy perceptions and that these concepts are in a positive relationship with each other, it 
has been observed that as the self-efficacy of individuals increases, there is a directly proportional relationship between them. In the literature, many studies showed that the relationship between these two concepts was positive.

In this study, it was investigated whether there is a role of job satisfaction as an intermediary effect in leadership styles that affect employees' selfefficacy perceptions. In this context; The research was conducted on the employees of the shopping mall operating in Edremit District of Balıkesir. Due to the structure of the retailing sector, it was seen that the majority of the participants consisted of young and single women who have low education levels and paid around the minimum wage. In the research, first of all, the concepts were explained, a literature review was made and the findings in the previous studies were examined. In the application part, 201 questionnaires that were accepted as valid in the questionnaire forms prepared and distributed for the research were used as data sets in the research. In the correlation analysis applied for the variables in the study, it was found that transformational leadership had a significant relationship on both job satisfaction and self-efficacy, while interactive leadership had a low effect on job satisfaction and no self-efficacy.

Multiple regression analysis was applied in the study to test the interaction of variables over these results.In the regression analysis conducted on the effect of leadership style, which is the first hypothesis of the research, on job satisfaction, a positive change in general leadership style was found to increase job satisfaction positively by 0.330 units. In the literature, from other studies on this subject; Amount, etc. (2006) it was mentioned that transformational leadership significantly increased job satisfaction in employees and the low intention to quit in employees with such leaders. Chiok (2001) found that leadership behaviors have a $29 \%$ positive effect on job satisfaction, while Koçak and Özüdoğru (2015) found a positive and strong relationship on leadership satisfaction with managers and employees' job satisfaction. It seems that all these studies coincide with the findings of the research hypothesis.

In the second hypothesis that the effect of leadership style on self-efficacy was investigated, a positive and significant relationship was determined between the variables. According to this result, the change in leadership style increases the self-efficacy perception by 0.275 units. In the study con- 
ducted by Man (2011), it was mentioned that there is a significant and positive relationship between employees' perceptions of leadership and selfefficacy. Also, Choi et al. (2003) stated that there is a positive relationship between transformational leadership style and self-efficacy. As seen in related studies in the literature, leadership style perceptions have a positive effect on employees' self-efficacy.

In the main and final hypothesis of the study, it was seen that the mediating role of job satisfaction in the relationship of leadership grey self-efficacy was positive and significant, albeit at a low level. The leadership dimension, the dimension of meaning, which was 0.528 between self-efficacy, increased to 0.547 with the mediating role of job satisfaction. It can be said that the main reason for the increase in this effect is due to the positive effect of leadership grey perceptions on both self-efficacy and job satisfaction. In other words, positive and harmonious leadership practices have an added value on working personnel over other variables (motivation, performance, etc.). However, the reason for the low impact can be explained as the effect of the low correlation coefficient of the interactionist leadership on the transformational leadership in the analysis of transformational and interactive leadership as a whole.

No studies in the relationship between leadership greyhound selfefficacy with the participation of job satisfaction have been found in the literature. For this reason, it can be said that the purpose and results of the research will contribute to the literature in this regard.The fact that the study was conducted in a particular and narrow environment constitutes the biggest limitation of the study. On the other hand, it is thought that it would be more appropriate to generalize the results by comparing these and similar studies with comparative results by including different sectors instead of a single sector.

\section{Kaynakça / References}

Adler, S., Richard, B.S. ve Nat, J.S. (1985). Job characteristics and job satisfaction : when cause becomes consequence. Organizational Behaviour and Human Decision Processes, 35, 266-278.

Akgündüz, Y. (2013). Konaklama işletmelerinde iş doyumu, yaşam doyumu ve öz yeterlilik arasındaki ilişkinin analizi. Manisa Celal Bayar Üniversitesi Sosyal Bilimler Dergisi, 11(1), 180-204. 
Aytaç, M. ve Öngen, B. (2012). Doğrulayıcı faktör analizi ile yeni çevresel paradigma ölçeğinin yapı geçerliliğinin incelenmesi. Istatistikçiler Dergisi, 5, $14-22$.

Baltacı,A. (2017).Okul müdürlerinin iş doyumları ile öz yeterlik algıları arasındaki ilişki.Ihlara Ĕ̆itim Araştırmaları Dergisi, 2(1), 49-76.

Bandura, A. (1986).Social foundation of thought and action: A social cognitive theory. Englewood Clifts, NJ: Prentice-Hall.

Bandura, A. (1995).Exercise of personal and collective efficacy in changing societies.New York: Cambridge University Press. 1-45

Bass, B. M. ve Avolio, B. J. (2000), MLQ: Multifactor leadership questionnaire Redwood City. CA: Mind Garden.

Bass, B. (1985).Leadership and performance beyond expectations.New York:The Free Press.

Bingöl, D. (1997). İnsan kaynaklarr yönetimi. İstanbul: Beta Yayınları.

Buluç,B.(2009). İlkoğretim okullarında burokratik okul yapısı ile okul müdürlerinin liderlik stilleri arasındaki ilişki. Gazi Üniversitesi, 34(152),

Buluç, B. ve Demir, S. (2015). İlk ve ortaokul öğretmenlerinin öz-yeterlik algıları ile iş doyumları arasındaki ilişki.Ahi Evran Üniversitesi Kırşehir Eğitim Fakültesi Dergisi, 16(1), 289-308.

Chen, G. Gully, S. M. ve Eden, D. (2001). Validationof a new general selfefficacyscale. Organizational Research Methods, 4, 62.

Choi,S.L., Goh,C.F., Adam,M.B.H., ve Kowang,O.(2016). Transformational leadership,empowerment and job satisfaction: the mediating role of employee empowerment. Human Resources for Health 14(73). DOI 10.1186/s12960-016-0171-2

Chiok, F.L.J. (2001). Leadership behaviours: Effeccts on jop satisfaction, productivity. A Service of the National Library of Medicine and the National Institutes of Health, 9(4), 191-204.

Choi J. N. Price R. H. ve Vinokur A. D. (2003). Self-efficacy changes in grops efffect of diversity leadership and group climate. Journal of Organizational Behavior, 24, 357-372.

Çelik,S., Dedeoğlu,B.B., ve İnanır, A.(2015). Relationship between ethical leadership,organizational commitment and job satisfaction at hotel organizations. Ege Academic Review, 15(1), 53-63

Davis, K. (1988). İşletmede insan davranışı: Örgütsel davranış. (çev. K. Tosun vd.), İstanbul:İstanbul Üniversitesi, 
Den, H., Deanne, N., Van Muijen,J. J. ve Koopman, P. L. (1997). Transactional versus transformational leadership: An analysis of the MLQ. Journal of Occupational and Organizational Psychology, 70, 19-34

Durmaz, Ş. ve Ören, K. (2017). Öz yeterlilik ve özgüvenin işgücü ve istihdama etkisine bir bakış.Aksaray Üniversitesi İktisadi ve İdari Bilimler Fakültesi Dergisi, 9(1), 109-120

Durmuş, B.,Yurtkoru, S. ve Çinko, M. (2013). Sosyal bilimlerde SPSS'le veri analizi. İstanbul:Beta Yayıncilı.

Emery, C.R. ve Barker, K.J. (2007). The effects of transactional and transformational leadership sytles on the organizational commitment and job satisfaction of customer contact personel. Journal of Organizational Culture Communications and Conflict, 11(1), 77-90.

Erdoğdu, M. (2009). Osmaniye ilinde çalışan sağlık personelinin iş tatmini, öz yeterlilik düzeyi ve bunlara etki eden faktörlerin incelenmesi. 8. Ulusal Sağlık Kuruluşları Yönetim Kongresi, Marmaris

Etzioni, A. (1964). Modern organizations. USA:Engle-Wood Cliffs, Prentice-Hall, Newjersey.

Gençtürk, A. ve Memiş, A. (2010). İlköğretim okulu öğretmenlerinin öz yeterlik algıları ve iş doyumlarının demografik faktörler açısından incelenmesi. İlköğretim Online, 9(3), 1037-1054.

Graen, G. B. (1976). Role making processes within complex organizations. Handbook of Industrial and Organizational Psychology, içinde (s.1201-1245), Chicago: Rand-McNally,

Graen, G. ve Uhl-Bien, M. (1995). Relationship-based approach to leadership: Development of LMX theory of leadership over 25 years: Applying a multi-level multi domain perspective. Leadership Quarterly, 6(2), 219- 247.

Gürbüz, S., Erkuş, A., ve Sığrı, Ü. (2010). İş tatmini ve iş performansının yeni öncülü: temel benlik değerlendirilmesi.Sosyal ve Beşeri Bilimler Dergisi, 2(1), 1309 -8012.

İşcan,F. Ö., ve Çakır,S. (2016).Mentorluk ve psikolojik güçlendirmenin öz yeterlilik algısına etkisi.Süleyman Demirel Üniversitesi İktisadi ve İdari Bilimler Fakültesi Dergisi, 21(1), 1-15.

Koçak, R. D. ve Özüdoğru, H. (2012). Yöneticilerin liderlik özelliklerinin çalışanların motivasyonu ve performansı üzerindeki etkileri: Kamu ve özel hastanelerinde bir uygulama.Ticaret ve Turizm Eğitim Fakültesi Dergisi, 1, 76-88. 
Koh, W. L., Steers, R. M., ve Terborg, J. R. (1995). The effects of transformational leadership on teacher attitudes and student performance in Singapore. Journal of Organizational Behavior, 16, 319-333.

Köksal, F. ( 2008). Antrenörlerin liderlik tarzlan ile öz yeterlikleri arasındaki ilişki. Yayınlanmış Yüksek lisans Tezi, Selçuk Üniversitesi Sosyal Bilimler Enstitüsü, Konya.

Luthans, F. (1995). Organizational behavior. (3rd. Ed.),New York: Mc. Graw Hill Publishing., 170-172.

Man, M.R.D.R. (2011), "Leadersih and Self-Efficacy Towards Mission Accomplishment Among The Nursing Faculty of The Lyceum of The Philippines University", E-International Scientific Research Journal, 3/4, 225-231.

Medley, F. ve Larochelle, D.R. (1995), “Transformational leadership and job satisfaction", Nursing Management, 26, 64-5

Randhawa, G.(2004). Self-efficacyandwork performance: An empirical study.Indian Journal of Industrial Relations, 39(3), 336-34.

Ren,S. ve Chadee, D. (2017). Ethical leadership, self-efficacy and job satisfaction in China: the moderating role of guanxi.Personnel Review, 46(2), 371-388

Schwarzer, R. ve Jerusalem, M. (1979). General self-efficacy scale. In (R. Schwarzer Ed.), Selfefficacy: Thought control of action içinde (s.195-213.)

Steers, R. M. (1991). Introduction to organizational behavior.(4th edition) New York:Harper Collins Publishers.

Turcan, H. G. (2011). Illköğretim okulu öğretmenlerinin öz yeterlik algıları ile iş doyumları arasındaki ilişkinin incelenmesi. Yayınlanmış Yüksek lisans Tezi, Selçuk Üniversitesi Eğitim Bilimleri Enstitüsü, Konya.

Tutar, H., Tuzcuoğlu, F., Argün, Ç., ve Akman, E. (2009). Dönüştürücü/etkileşimci liderliğin örgütsel adanmışlık üzerine etkisi: Karşılaştırmalı bir çalışma.International Davraz Congress on Social and Economic Issues Shaping the World's Future; New Global Dialogue, 14-27, 1384-1396.

Toklu, O. (2010).Tenis antrenörlerinde liderlik özellikleri ve öz yeterlilik arasındaki ilişkinin belirlenmesi. Yayınlanmış Yüksek lisans Tezi, Selçuk Üniversitesi Sağlık Bilimleri Enstitüsü , Konya.

Weiss, D. J., Dawis, R. V. England, G. W. ve Lofquist, L. H. (1967). Manual for the minnesota satisfaction questionnaire. Minnesota Studies in Vocational Rehabilition, Minneapolis, University of Minnesota, Industrial Relations Center, 22. 
Yurtkoru, S. (2001). The role of leadership in the organizational change process. Yayımlanmamış Doktora Tezi, Marmara Üniversitesi, Sosyal Bilimler Enstitüsü, İstanbul.

\section{Kaynakça Bilgisi / Citation Information}

Örücü, E.,Şeker, C. ve Kaya, A. (2020).Öz yeterlilik algisi ve liderlik tarzi ilişkisinde iş tatmininin aracilik rolü. OPUS-Uluslararası Toplum Araştırmaları Dergisi, 15(24), 2335-2361. DOI:10.26466/opus.683963 